\title{
Some aspects of the palaeobiology of Tertiary deep-Sea Ostracoda from the S.W. Pacific
}

\author{
ROBIN WHATLEY \\ Department of Geology, University College of Wales, Aberystwyth, U.K.
}

\begin{abstract}
From a numerical analysis of deep water Neogene and Quaternary Ostracoda from D.S.D.P. sites in the S.W. Pacific, it is shown that the Miocene to Quaternary interval saw a large scale invasion by bathyal stocks of the abyss. This invasion was progressive and cumulative and resulted in abyssal faunas being much more diverse in the Quaternary than they had been in the Miocene. This major palaeoecological shift also occasioned a concommitant decline in bathyal faunas over the same interval. The breakdown of bathyal and abyssal isolation resulted from the Miocene onwards, in a progressive increase in the number of species which were able, contemporaneously, to live at both bathyal and abyssal palaeodepths.

The study shows deep water faunas of this age to be much more diverse than previous studies have indicated. Ninety-one genera with autochthonous deep water species are encountered in this study. These genera are listed with the numbers of species of each genus and their depth distribution for Miocene, Pliocene and Quaternary respectively. Overall species diversity declines from the Miocene to the Pliocene but steeply increases into the Quaternary. It is suggested that the Pliocene impoverishment may in part be an artefact, occasioned by abnormally high Miocene diversity.

It is shown that the phenomena outlined above are, to varying degrees, illustrated by all of the 6 groups into which the fauna is divided. It is suggested that certain of these phenomena, such as the major downslope migration from the Miocene onwards, may be detectable in other parts of the world's oceans.
\end{abstract}

\section{INTRODUCTION}

This paper presents some of the results of a study being undertaken at Aberystwyth into Upper Cretaceous to Recent deep sea benthonic Ostracoda. Material has been examined from all of the world's oceans but with particular emphasis on the North Atlantic and S.W. Pacific Oceans. The present paper is a compilation of some of the results obtained from the Neogene and Quarternary of the latter area and, while incorporating some additional data, conforms in all major respects to the address given by the author to the British Micropalaeontological Society on 17th November 1982.

The aim of the project is to conduct, for the first time, a detailed and comprehensive study of the entire benthonic ostracod fauna in order to promote a better understanding of its origins, taxonomic composition, evolution, palaeoecology and palaeobiology. The achievement of these aims has been in some measure frustrated by the very newness of the fauna. A very high percentage of the species and not a few genera are new and this has necessitated a large initial emphasis on descriptive work. Despite this, considerable progress has been made in a number of areas.

Although much of our knowledge of Recent deep sea Ostracoda is still based upon the results of the Challenger Expedition (Brady, 1880; Puri \& Hulings, 1976) a growing number of studies on deep sea Tertiary and Recent Ostracoda have appeared in Recent years. Among these are: Benson, 1969, 1971, 1972a, b, 1974, 1975, 1976, 1977, 1978, 1982; Benson \& SylvesterBradley, 1971; Ducasse \& Peypouquet, 1979; Joy \& Clark, 1977; Malz, 1981 ; Peypouquet, 1975, 1977, 1979; Steineck, 1981; Swain, 1970a, b; Whatley et al., 1982, in press $\mathrm{a}, \mathrm{b}, \mathrm{c}$.

A major deficiency of many of these contributions has been their somewhat select nature. For example, Benson, the major contributor to these studies has largely concentrated on a single family of ornate Ostracoda, the Trachyleberididae, to support his theories on global palaeoceanography and the evolution of carapace architecture etc. Similarly, Peypouquet has been primarily concerned with demonstrating the potential of two genera, Krithe and Parakrithe, as palaeoenvironmental and particularly depth indicators.

As a consequence of these studies, any student reading the literature on Tertiary and Recent deep sea ostracod faunas could be forgiven for concluding that the generic and specific diversity of these faunas was very low. How wrong they will be! This paper demonstrates that deep sea ostracod faunas are much more diverse than prior studies would indicate. 
The deep sea environment is a complex mixture of the hostile and the benign. On the one hand, since about the end of the Eocene it has been very cold. Abyssal temperatures range from $0^{\circ}-4^{\circ} \mathrm{C}$ and bathyal temperatures from $4^{\circ}-7^{\circ}$ or $8^{\circ} \mathrm{C}$. There is no light, pressure is high and the threat of dissolution of shell material is never far away at abyssal depths. On the other hand, there is great stability. There are no diurnal nor seasonal variations in temperature, light or salinity etc. There are high concentrations of nutrient salts, particularly nitrates and phosphates and oxygen is plentiful. Energy levels are generally low and a food supply exists in the continuai rain of dead plankton.

In the main, the virtues seem to outweigh the disadvantages. Certainly, large numbers of different animals of very diverse morphology and mode of life live at these depths, not least among them the Ostracoda.

Most of the micropalaeontological effort associated with the D.S.D.P. programme has been devoted to the study of pelagic microfossils. One intention of this paper is to promote greater micropalaeontological interest in the benthos.

\section{LOCATION OF THE STUDY AREA}

The study is based on a total of 156 samples from 19 D.S.D.P. sites and 5 samples of Miocene age collected by a French Expedition in the Loyalty Basin. The location of the sites and an indication of their gross stratigraphy is given in Fig. 1 and further data is given in Table 1.

In Fig. 1, drawn on the bathymetric map, is a line separating a Northern "Abyssal" Province and a Southern "Bathyal" Province. Palaeodepths between $1000 \mathrm{~m}$ and $2000 \mathrm{~m}$ are referred to as bathyal and those greater than $2000 \mathrm{~m}$ as abyssal.

The most important D.S.D.P. sites in the Southern "Bathyal" Province are Site 209, on the Queensland Plateau and Sites 208, 207 and 284 on the Lord Howe rise. These sites have been continuously sampled throughout the Tertiary and Quaternary. During the Palaeocene and early Eocene, these sites were at outer shelf depths and many of the species had eyes and the fauna includes such warm water indications as Cytherelloidea as dominants. The Queensland Plateau and Lord Howe Rise, through the later Palaeogene slowly subsided to the bathyal depths (1300-1500 m) which were achieved by the Miocene (Burns \& Andrews, 1973; Packham \& Andrews, 1975). From the late Palaeogene, ostracod faunas at these sites contain no sighted species and Cytherelloidea, for example, is absent.

To the N. and N.E. of the line the sites we have studied were probably at abyssal depths for most or all of the Tertiary. In these we find a distinct fauna of abyssal character from which genera such as Cytherelloidea were always excluded, as were sighted species.

The only guyot we have studied is situated in the Northern Abyssal Province. The summit of this flat-

Table 1. The D.S.D.P. sites: their location, present day water depth and age of samples.

\begin{tabular}{|c|c|c|c|c|c|}
\hline & Site & Systems studied & $\begin{array}{l}\text { Present day } \\
\text { water depth }\end{array}$ & Lat. & Long. \\
\hline \multirow{6}{*}{ 莺 } & 277 & Quaternary & $1214 \mathrm{~m}$ & $52^{\circ} 13.43^{\prime} \mathrm{S}$ & $166^{\circ} 11.48^{\prime} \mathrm{E}$ \\
\hline & 281 & Quaternary & $1591 \mathrm{~m}$ & $47^{\circ} 59.84^{\prime} \mathrm{S}$ & $147^{\circ} 45.85^{\prime} \mathrm{E}$ \\
\hline & 284 & Quaternary & $1066 \mathrm{~m}$ & $40^{\circ} 30.48^{\prime} \mathrm{S}$ & $167^{\circ} 40.81^{\prime} \mathrm{E}$ \\
\hline & 207 & Neogene to Quaternary & $1389 \mathrm{~m}$ & $36^{\circ} 57.75^{\prime} \mathrm{S}$ & $165^{\circ} 26.06^{\prime} \mathrm{E}$ \\
\hline & 208 & Neogene to Quaternary & $1545 \mathrm{~m}$ & $26^{\circ} 06.61^{\prime} \mathrm{S}$ & $161^{\circ} 13.27^{\prime} \mathrm{E}$ \\
\hline & 209 & Neogene to Quaternary & $1428 \mathrm{~m}$ & $15^{\circ} 56.19^{\prime} \mathrm{S}$ & $152^{\circ} 11.27^{\prime} \mathrm{E}$ \\
\hline & 282 & Quaternary & $4202 \mathrm{~m}$ & $42^{\circ} 14.67^{\prime} \mathrm{S}$ & $143^{\circ} 29.18^{\prime} \mathrm{E}$ \\
\hline & 279 & Quaternary & $3341 \mathrm{~m}$ & $51^{\circ} 20.14^{\prime} \mathrm{S}$ & $162^{\circ} 38.10^{\prime} \mathrm{E}$ \\
\hline & 206 & Pliocene to Quaternary & $3196 \mathrm{~m}$ & $32^{\circ} 00.75^{\prime} \mathrm{S}$ & $165^{\circ} 27.15^{\prime} \mathrm{E}$ \\
\hline & 262 & Quaternary & $2298 \mathrm{~m}$ & $10^{\circ} 52.19^{\prime} \mathrm{S}$ & $123^{\circ} 50.78^{\prime} \mathrm{E}$ \\
\hline & 288 & Neogene & $3000 \mathrm{~m}$ & $5^{\circ} 38.35^{\prime} \mathrm{S}$ & $161^{\circ} 41.53^{\prime} \mathrm{E}$ \\
\hline & 289 & Neogene to Quaternary & $2206 \mathrm{~m}$ & $0^{\circ} 29.92^{\prime} \mathrm{S}$ & $158^{\circ} 30.69^{\prime} \mathrm{E}$ \\
\hline & 62 & Neogene & $2591 \mathrm{~m}$ & $10^{\circ} 52.2^{\prime} \mathrm{N}$ & $141^{\circ} 56.3^{\prime} \mathrm{E}$ \\
\hline & 64 & Neogene to Quaternary & $2052 \mathrm{~m}$ & $1^{\circ} 44.4^{\prime} \mathrm{N}$ & $158^{\circ} 36.54^{\prime} \mathrm{E}$ \\
\hline & 55 & Neogene & $2850 \mathrm{~m}$ & $9^{\circ} 18.1^{\prime} \mathrm{N}$ & $142^{\circ} 32.1^{\prime} \mathrm{E}$ \\
\hline & 56 & Miocene & $2508 \mathrm{~m}$ & $8^{\circ} 22.4^{\prime} \mathrm{N}$ & $143^{\circ} 33.6^{\prime} \mathrm{E}$ \\
\hline \multirow{3}{*}{ 方 } & 57 & Pliocene & $3300 \mathrm{~m}$ & $8^{\circ} 40^{\prime} \mathrm{N}$ & $143^{\circ} 32.0^{\prime} \mathrm{E}$ \\
\hline & 47 & Pliocene & $2689 \mathrm{~m}$ & $32^{\circ} 27^{\prime} \mathrm{N}$ & $157^{\circ} 43^{\prime} \mathrm{E}$ \\
\hline & 200 & Neogene & $1469 \mathrm{~m}$ & $12^{\circ} 50.2^{\prime} \mathrm{N}$ & $156^{\circ} 47.0^{\prime} \mathrm{E}$ \\
\hline
\end{tabular}




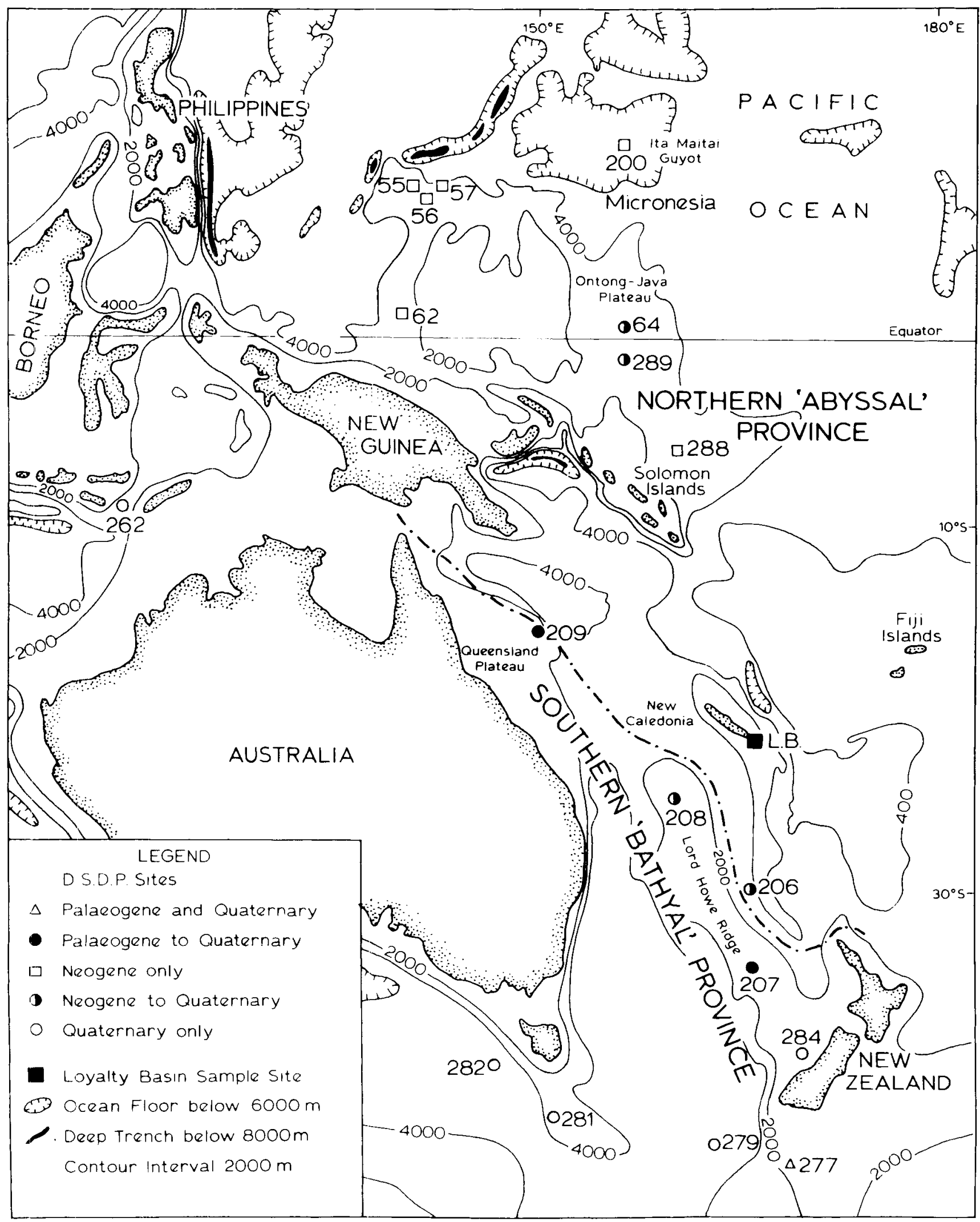

Fig. 1. Bathymetric map of S.W. Pacific with D.S.D.P. sites and their gross stratigraphy. 
Table 2. The Stratigraphical and depth distribution of the fauna. $B=$ Bathyal, $A=A$ byssal

\begin{tabular}{cccccccccccccc} 
& \multicolumn{3}{c}{} & \multicolumn{3}{c}{ MIOCENE } & \multicolumn{4}{c}{ PLIOCENE } & \multicolumn{4}{c}{ QUATERNARY } \\
\cline { 2 - 11 } Genera & Total & No. & No. & No. & Total & No. & No. & No. & Total & No. & No. & No. \\
& No. & B. & B + & A. & No. & B. & B + & A. & No. & B. & B + & A. \\
& spp. & spp. & A. spp. & spp. & spp. & spp. & A. spp. & spp. & spp. & spp. & A. spp. spp.
\end{tabular}

\section{GROUP 1}

Cardobairdia

Neonesidae

Paranesidea

Bairdoppilata

Bythocypris

Zabythocypris

Macrocypria

Propontocypris

Cyprid gen. nov.

Argilloecia

Australoecia

Abyssocypris

Paracypris

Anchistrocles

Macrocypris

$\begin{array}{rrrrrrr}1 & 1 & & & 2 & & 2 \\ 1 & 1 & & 1 & & & \\ 1 & & & 1 & 3 & 2 & \\ 3 & 2 & & 1 & 2 & 2 & \\ 6 & 5 & & & 3 & 2 & 1 \\ 1 & 1 & & & & & \\ 1 & 1 & & & 1 & 1 & \\ 2 & 2 & & 1 & 1 & 1 & \\ 3 & 2 & & 5 & 11 & 9 & 2 \\ 17 & 11 & 1 & 2 & 3 & 3 & \\ 4 & 1 & 1 & 3 & 1 & & \\ 5 & 2 & & & 1 & 1 & \\ 1 & 1 & & & & & \end{array}$

2

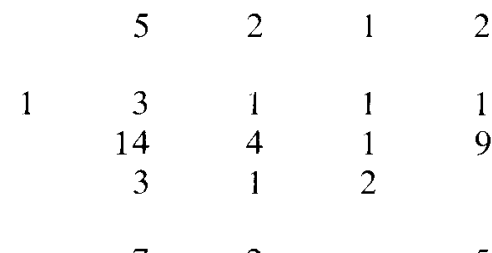

\begin{tabular}{|c|c|c|c|c|}
\hline & 7 & 2 & & 5 \\
\hline \multirow{6}{*}{1} & 2 & 2 & & \\
\hline & 21 & 9 & 5 & 7 \\
\hline & 15 & 9 & 1 & 5 \\
\hline & 2 & 1 & & 2 \\
\hline & 5 & 3 & & 2 \\
\hline & 4 & 1 & & 3 \\
\hline & 3 & 1 & 1 & 1 \\
\hline
\end{tabular}

\section{GROUP 2}

Krithe

Parakrithe

$\begin{array}{rr}43 & 25 \\ 3 & 1\end{array}$

$\begin{array}{rrr}18 & 43 & 26 \\ 2 & 2 & 1\end{array}$

$\begin{array}{rrrrr}17 & 54 & 20 & 15 & 19 \\ 1 & 5 & 1 & & 4\end{array}$

\section{GROUP 3}

Bythocytheromorpha

Cretaceratina

Cytheralison

Pseudoloxoconcha

Gen. nov. 1

Indet. gen. 1

Bythocythere

Bythoceratina

Gen. nov. 2

Pseudocythere

Phlyctobythocythere

Orientobythere

Indet. gen. 2

$\begin{array}{ll}2 & 2 \\ 1 & 1 \\ 4 & 4 \\ 2 & 2 \\ 2 & 2 \\ 1 & 1\end{array}$

\section{GROUP 4}

Eucythere

Cytheropteron

Aversovalva

Eucytherura

$\begin{array}{rr}18 & 14 \\ 30 & 22 \\ 9 & 8 \\ 13 & \end{array}$

GROUP 5

Bradleya

Quasibradleya

Poseidonamicus

"Trachyleberis"

$\begin{array}{rrrrrrrrrrrr}12 & 10 & 1 & 1 & 7 & 5 & 1 & 1 & 13 & 6 & 2 & 5 \\ 1 & 1 & & & 6 & 1 & 3 & 2 & 7 & 3 & 3 & 1 \\ 4 & 3 & 1 & & 6 & & & & & & \end{array}$


Actinocythereis Acanthocythereis

Gen. nov.

Atlanticythere

Abyssocythere

Henryhowella

Echinocythereis

Toolongella

Indet. gen. 1

Indet. gen. 2

Indet. gen. 3

Indet. gen. 4

Indet. gen. 5

Indet. gen. 6

Indet. gen. 7

Agrenocythere

Ambocythere

Cletocythereis

"Thalassocythere"

Indet. gen. 8

Indet. gen. 9

Indet. gen. 10

Indet. gen. 11

Indet. gen. 12

"Oxocythereis"

Phacorhabdotus

Indet. gen. 13

Indet. gen. 14

Indet. gen. 15

Indet. gen. 16

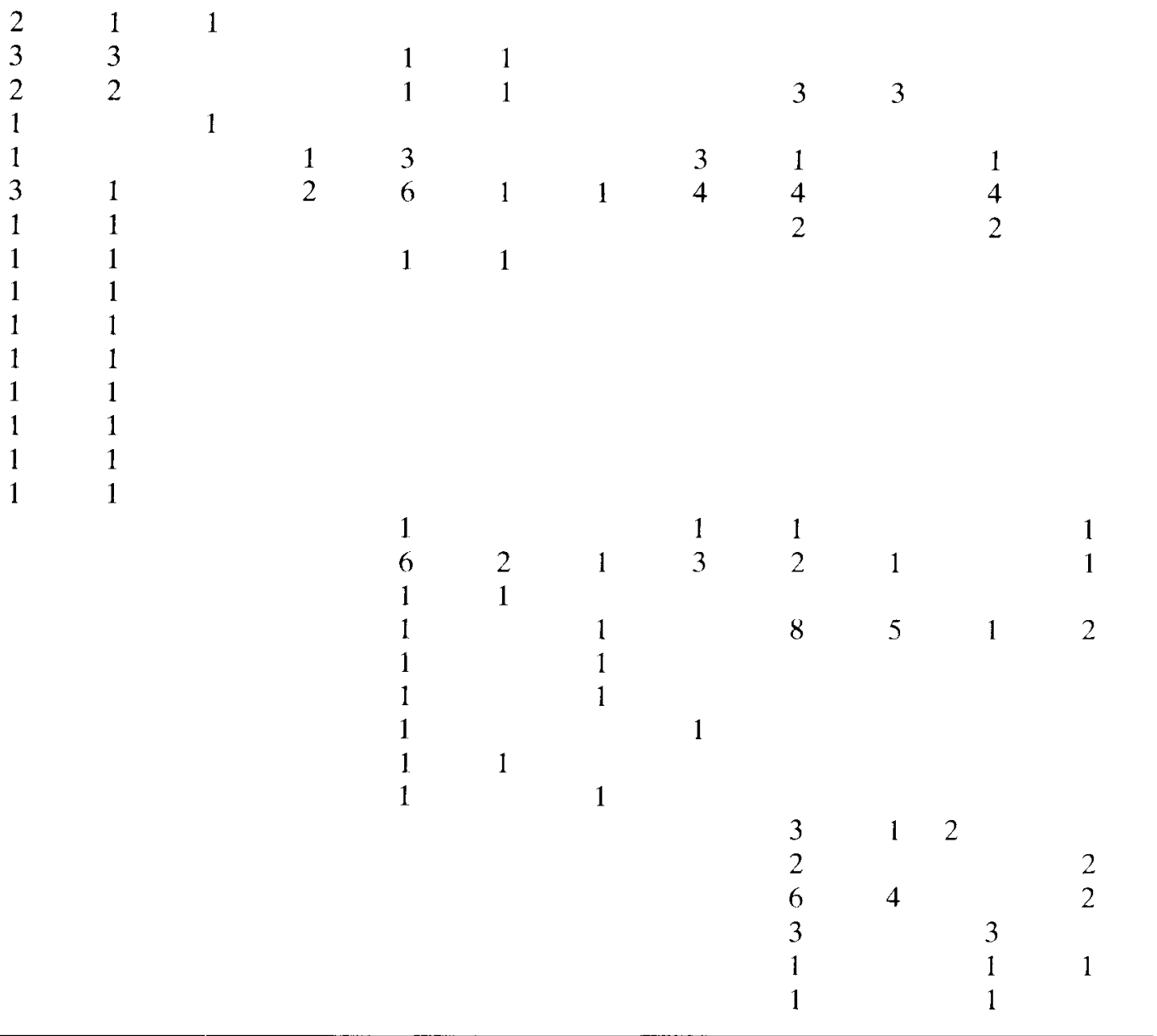

\section{GROUP 6}

Saida

Bosquetina

Rockallia

Typhlocythere

?Semicytherura

Paracytheridea

Pedicythere

Swainocythere

Pelecocythere

Loxoconcha

Indet. gen.

Abyssocythereis

Xestoleberis

Cytherella

Cytherelloidea

Polycope

Copytus

Hemicytherura

Cluthia

Paijenborchella

Cytherura

Paradoxostoma

Manawa
2

2
1
1
1
1
1
1
1
1
1
1
1
5
4
2
3

1
1
1
1

1
4
2
2
3

1

1
1
1

1

$\begin{array}{llllll} & & 3 & 1 & & 2 \\ 1 & 1 & 2 & & 1 & 1 \\ 1 & & 3 & 1 & 1 & 1 \\ & & 2 & 1 & & 1\end{array}$

1

$2 \quad 2$

$\begin{array}{lll}3 & 2 & 1\end{array}$

1

$\begin{array}{ll}2 & 1 \\ 1 & 1\end{array}$

53

2

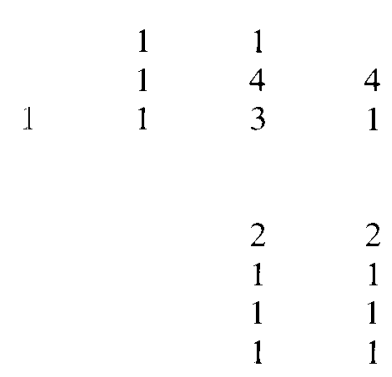

2

4

$\begin{array}{llll}6 & 1 & 1 & 3 \\ & 1 & 4\end{array}$

$4 \quad 4$

$1+1$

$\begin{array}{lll}1 & 1 & \\ 5 & 1 & 4\end{array}$

$\begin{array}{lll}1 & 1 & \\ 5 & 3 & 2\end{array}$

$\begin{array}{lll}5 & 3 & 2 \\ 1 & & 1\end{array}$ 
topped seamount, the Ita Mai Tai Guyot, was throughout most, if not all of the Tertiary, at some $1400 \mathrm{~m}$ but was, and is, surrounded on all sides by an abyssal plain at some $6000 \mathrm{~m}$.

\section{COMPOSITION OF THE FAUNA}

With the exception of detailed studies on such genera as Rockallia, Bradleya and Poseidonamicus (Whatley et al., 1981, Whatley et el., in press a, b, c). Our studies on the Palaeogene of the area are incomplete and since numerical data are not yet available for the early Tertiary, this paper will be restricted to a consideration of faunas and events in the Neogene and Quaternary.

In the Neogene and Quaternary we have encountered 91 genera. Their gross depth distribution and the number of species of each genus occurring in the Miocene, Pliocene and Quaternary of the area is given in Table 2. The number of species in each of these divisions which are confined to bathyal or abyssal palaeodepths and those which occur in both are also given. Genera to be described in due course as new are deliberately left in open nomenclature. Many of the unidentified genera are new but lack sufficient material to allow them to be so designated.

The list of genera are presented under 6 group headings which will be explained below. In this list and in subsequent Figs., species from the Ita Mai Tai Guyot are treated as bathyal.

Gross statistics on the faunas are as follows:

$\begin{array}{lll}\text { Quaternary } & 365 \text { species } & 58 \text { genera } \\ \text { Pliocene } & 200 \text { species } & 50 \text { genera } \\ \text { Miocene } & 238 \text { species } & 62 \text { genera }\end{array}$

The decline in the number of taxa, particularly species, from Miocene to Pliocene is well shown in Fig. 2 as is the steep increase in the number of species into the Quaternary. The reasons for this Pliocene impoverishment are not easily found and the author knows of no parallel among other Pliocene faunas. Indeed, the specific diversity of the Upper Pliocene of Cornwall and N.W. France is approximately 600 ; greater than any previously known ostracod fauna (Maybury verb. comm. 1983). Similarly, it is difficult to equate this phenomenon to climatic deterioration since benthonic faunas should be largely insulated from this and also because of the pronounced enhancement of diversity in the same area during the Quaternary.

Possibly the answer will be more readily discernable when the data for the Palaeogene is available. This may demonstrate that the apparent Pliocene "low" is, in fact, due to a Miocene "high". This may have been in response to global climatic and oceanographic events (Savin et al., 1975; Shackleton \& Kennett, 1975a, b; Moore, Pisias \& Keigwin, 1981). Evidence of enhanced diversity of Bradleya and Poseidonamicus in the Miocene of the same area (Whatley et al., in press a, b, c) may be confirmatory evidence of this.

The Neogene and Quaternary deep water fauna of this region is very distinctive in its composition. Many elements which on contemporary shelf seas in the same area are dominants (Swanson, 1969; Hornibrook, 1952; McKenzie, 1974; Kingma, 1948; Keij, 1979, a, b; Whatley \& Downing, in press) are absent in the deep water facies or occur in very reduced circumstances. Among these, for example, are loxoconchids, leptocytherids pectocytherids, paradoxostomatids hemicytherids, leptocytherids, xestoleberids, many groups of cytherurids and some bairdiaceans. As yet unpublished work in the northern Indian Ocean and North Atlantic

\begin{tabular}{|c|c|}
\hline 12 DSDP sites & 52 samples \\
\hline 12 DSDP sites & 61 samples \\
\hline $\begin{array}{l}10 \text { DSDP sites } \\
+ \text { Loyalty Basin }\end{array}$ & 48 samples \\
\hline
\end{tabular}

confirms this clear distinction between Neogene and Quarternary deep water and shelf faunas.

Krithe is the dominant genus in virtually every sample and is very diverse. Marine cyprids, particularly Argilloecia are also very diverse and bairdiaceans are quite diverse.

The Bythocytheridae are somewhat patchy in both depth and stratigraphical distribution but are moderately diverse taken overall. Eucythere (s.s. and the subgenus Rotundracythere), Cytheropteron, Aversovalva (which we have good evidence to consider as a distinct genus) and Eucytherura are all very diverse, particularly Cytheropteron which is second only to Krithe.

The Trachyleberididae are, as a family, very diverse; particularly Bradleya and Poseidonamicus.

Other forms which are not diverse nor often abundant, occur consistently and are very characteristic of Neogene to Recent faunas worldwide. They include such genera as Saida, Rockallia and Pelecocythere.

Curiosities among the fauna include the abyssal genus Abyssocythereis, a survivor of the essentially late Mesozoic Protocytheridae. Other Mesozoic relicts are such genera as Toolongella originally described from the Upper Cretaceous of Western Australia by Bate (1972) and which survives in bathyal palaeodepths to the Pliocene. Similarly, Cretaceratina trispinosa Neale, 1975 survives on the Ita Mai Tai Guyot to the Miocene.

A single specimen of a new species of the palaeocopid genus Manawa has been encountered in the Quaternary and a distinct species group of the normally phytal genus Xestoleberis occurs at both bathyal and abyssal palaeodepths. The author has seen similar species in the Quaternary of the North Atlantic at similar palaeodepths.

Throughout this study I have carefully distinguished between autochthonous and allochthonous elements. Many of the latter are familiar from personal studies of 
shelf forms or from a study of the literature. Species are considered to be autochthonous by virtue of high incidence and an appropriate population age structure. More than 100 species have been rejected as allochthonous, mainly in the Quaternary.

\section{ORIGINS OF THE FAUNA}

Until the data on the Palaeogene fauna is available, it is not possible to provide precise evidence for the origins of the Neogene fauna. However, it can be shown to comprise two distinct components:

1. Forms which had entered the deep sea prior to the Miocene; some perhaps as early as the Cretaceous. By the Miocene (and probably earlier) the members of this group are more or less regularly distributed throughout both bathyal and abyssal environments. Krithe is one such example (Table 2). In the Miocene, this genus is almost equally diverse at all of the 11 DSDP sites, bathyal and abyssal, although overall there are more bathyal than abyssal species.

2. Forms which entered the deep sea later than those of group 1 (probably late Palaeogene) and which, in the Miocene are much more bathyal than abyssal in their depth distribution. Elsewhere it has been shown that Bradleya and Poseidonamicus are good examples of this group (Whatley et al., in press a, b, c). Table 2 also illustrates this phenomenon with respect to these two genera and also others, such as Cytheropteron, Argilloecia and many more. Many genera in this group, however, in the interval Miocene to Quaternary illustrate a major downslope migration into the abyss e.g. Cytheropteron.

Whatley et al. (in press a, b, c) have shown by detailed studies of various lineages of Bradleya and Poseidonamicus throughout the Tertiary that this region is an important locus for induction into the deep sea. This was caused by the previously mentioned subsidence of the area between Australia and New Zealand during the Palaeogene at a rate slow enough for elements of the fauna to adjust and to survive. This subsidence brought elements of shelf faunas involuntarily down to bathyal depths by the late Palaeogene. In due course, this newly established bathyal fauna migrated outwards from this locus into deeper water. Although this migration probably also occurred into abyssal depths to the south, we are only able to document it into the Northern "Abyssal" Province.

\section{THE MIOCENE TO QUATERNARY INVASION OF THE ABYSS}

An examination of the depth distribution of Miocene to Quaternary deep water Ostracoda in the S.W. Pacific (Fig. 3) shows an increase, with time, in the number of bathyal species which enter the abyssal realm. It also shows an overall decline in the number and percentage of bathyal species and complementary increases in the number of species confined to abyssal palaeodepths. Notwithstanding this major ecological shift, bathyal only species, by both total number and percentage, dominate the deep water fauna. However, by the Quaternary the progressive occupation of the abyss has resulted in near parity in bathyal and abyssal specific diversity. This change from the difference in diversity between the two realms in the Miocene is dramatic as is the progressive increase in the number of species which are encountered in both realms, particularly from the Pliocene onwards. In Fig. 3 and in many instances in Figs. 4-8, the graphs clearly reflect the apparent impoverishment of the Pliocene.

Fig. 4 illustrates the number and percentage of genera which are confined to bathyal and abyssal palaeodepths and also those genera with species which occur in both realms. The graphs clearly show a steep decline in genera confined to bathyal palaeodepths. The increase in genera confined to the abyss is small while the number and percentage of genera represented in both realms, particularly since the Pliocene is notable.

In order to determine whether certain elements were more involved than others in this invasion of the abyss, the fauna has been divided into 6 groups. Although these groupings are somewhat arbitrary, it is thought preferable to a division into families, for example, which exercise would have involved too many categories to maintain clarity and cohesion. The 6 groups are:

1 Bairdiacea and Cypridacea

(15 genera)

2 Krithe and Parakrithe

3. Bythocytheridae (13 genera)

4. Eucythere, Cytheropteron, Aversovalva and Eucytherura

5. Trachyleberididae

6. Other genera

(34 genera)

( 23 genera)

The genera in Table 2 are arranged according to these 6 groups and Fig. 5 illustrates the Miocene to Quaternary numerical and percentage distribution of the species and the percentage distribution of the genera of each group. Although each group illustrates a decline in species diversity from Miocene to Pliocene, which in groups 1 and 4 is steep, all exhibit enhanced diversities in the Quaternary. This diversity increase is notable in all cases but particularly so with respect to group 1 . The percentage of species of each group in the total fauna, however, shows an overall decrease in groups 2 and 4 , and an overall increase in groups 1,3 and 6. Both groups 2 and 5 enjoyed a higher percentage importance in the Pliocene than earlier or later.

With respect to genera, groups 1,5 and 3 exhibit an overall percentage decline, while groups 6 and 4 illustrate an increase.

The various phenomena exhibited in Fig. 5 will be largely explained in the discussion of Figs. 6-8. In these figures the species and genera of each group are considered with reference to their palaeodepth distribution 
through the Miocene to Quaternary interval.

Fig. 6 plots graphically the numerical distribution of the species of each group according to whether they are confined to bathyal or to abyssal palaeodepths or whether they occur in both realms. Fig. 7 plots the three categories of species of each group as percentages of the total fauna of each group in each system.
Group 1, although illustrating an overall increase in the number of bathyal only species shows a clear decline, from the Pliocene, in their percentage of the total group 1 fauna. Abyssal only species in this group decline from the Miocene to the Pliocene but increase steeply in the Quaternary where numerically and by percentage they exactly equal the bathyal only species. Species occurring

Fig.2. Total number of genera and species, Miocene to Quaternary and number of common species.

Miocene and Pliocene 62 Miocene, Pliocene and Quaternary 51

Pliocene and Quaternary 100

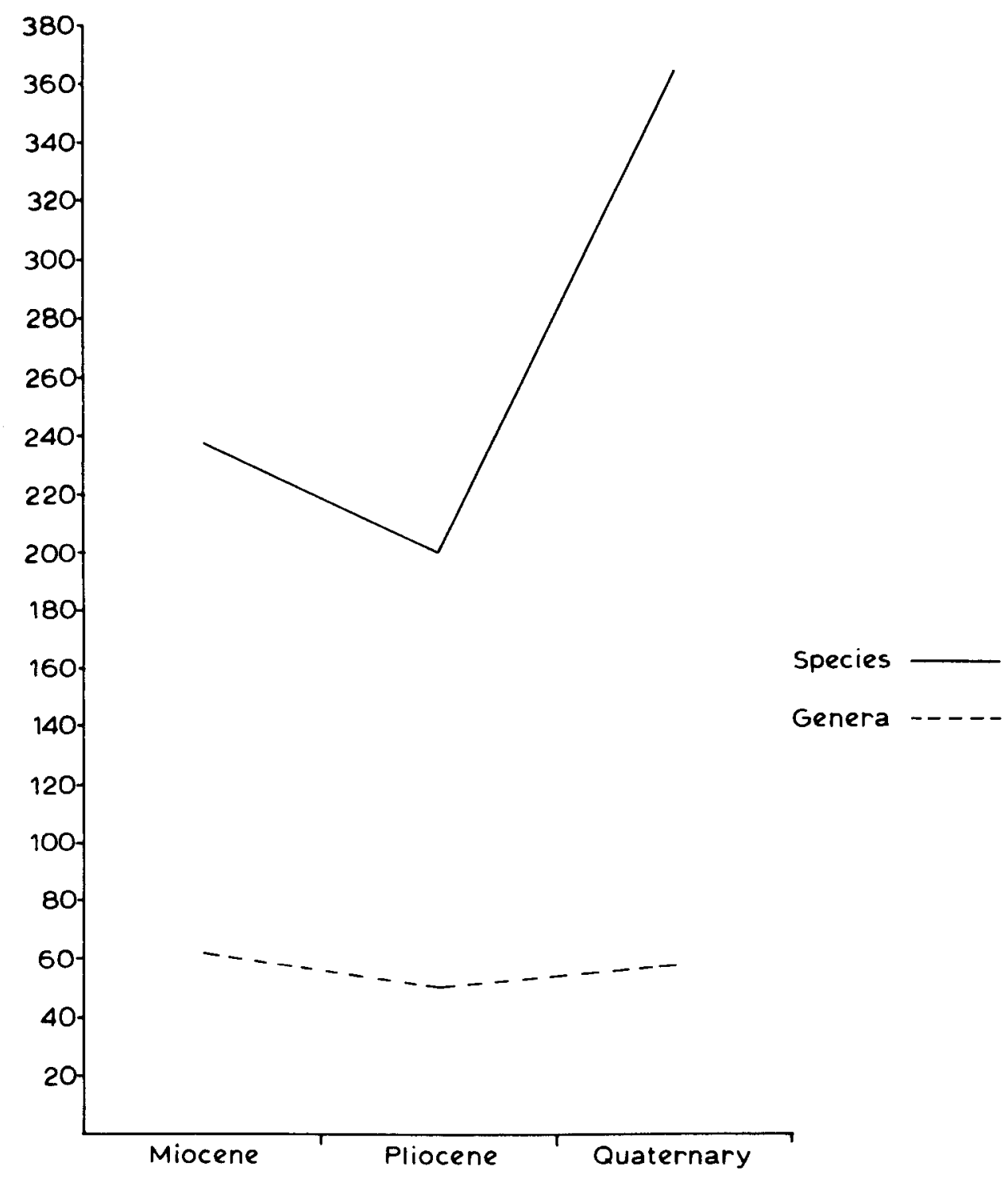


in both realms also increase overall. Although the main features illustrated by the group as a whole can be demonstrated by a number of genera, perhaps the best example is Argilloecia (Table 2). In the Miocene this

Fig. 3. Number and $\%$ of species confined to bathyal and to abyssal depths and of those which are both bathyal and abyssal.

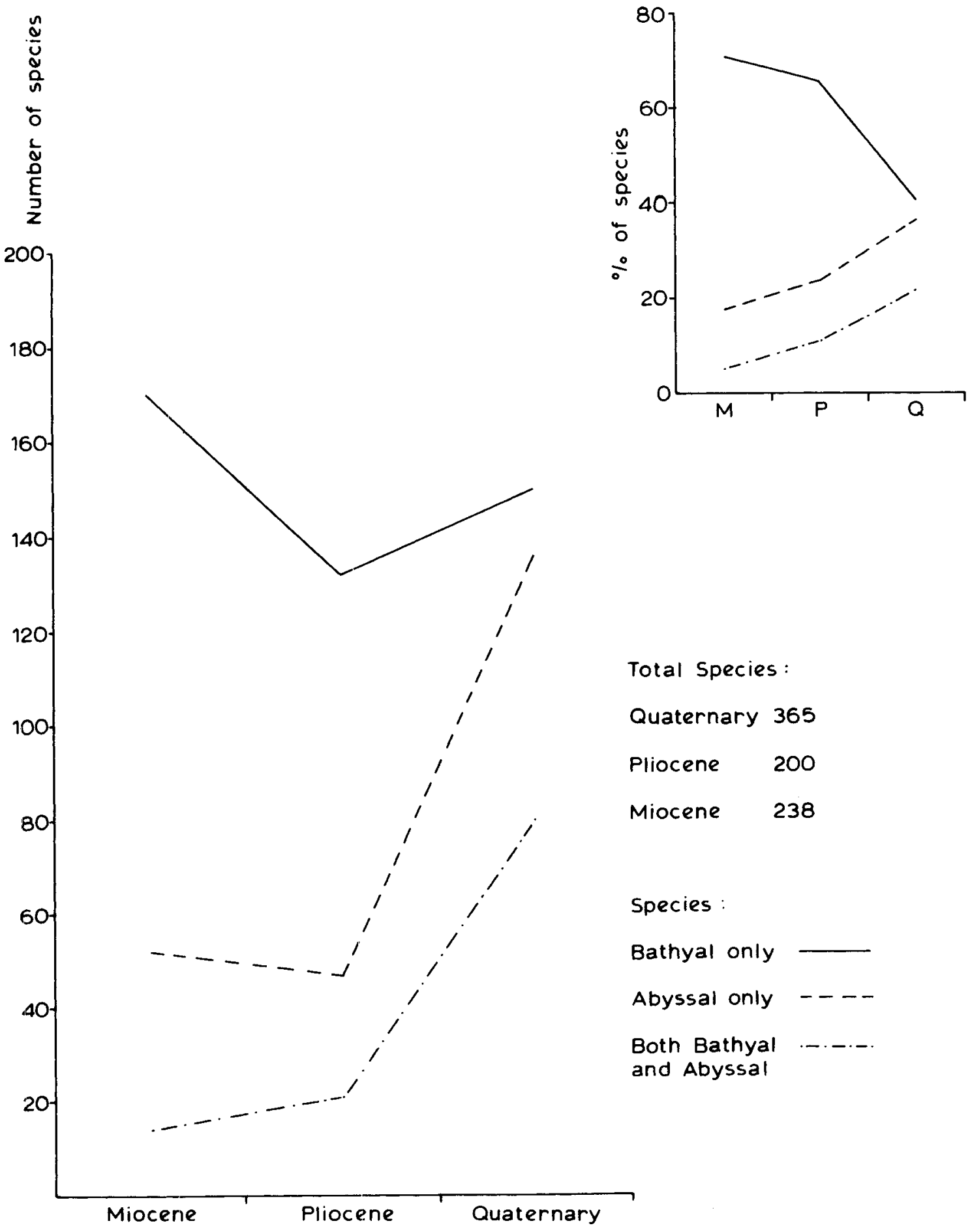


Fig.4. Number and $\%$ of genera confined to bathyal and to abyssal depths and of those which are both bathyal and abyssal.

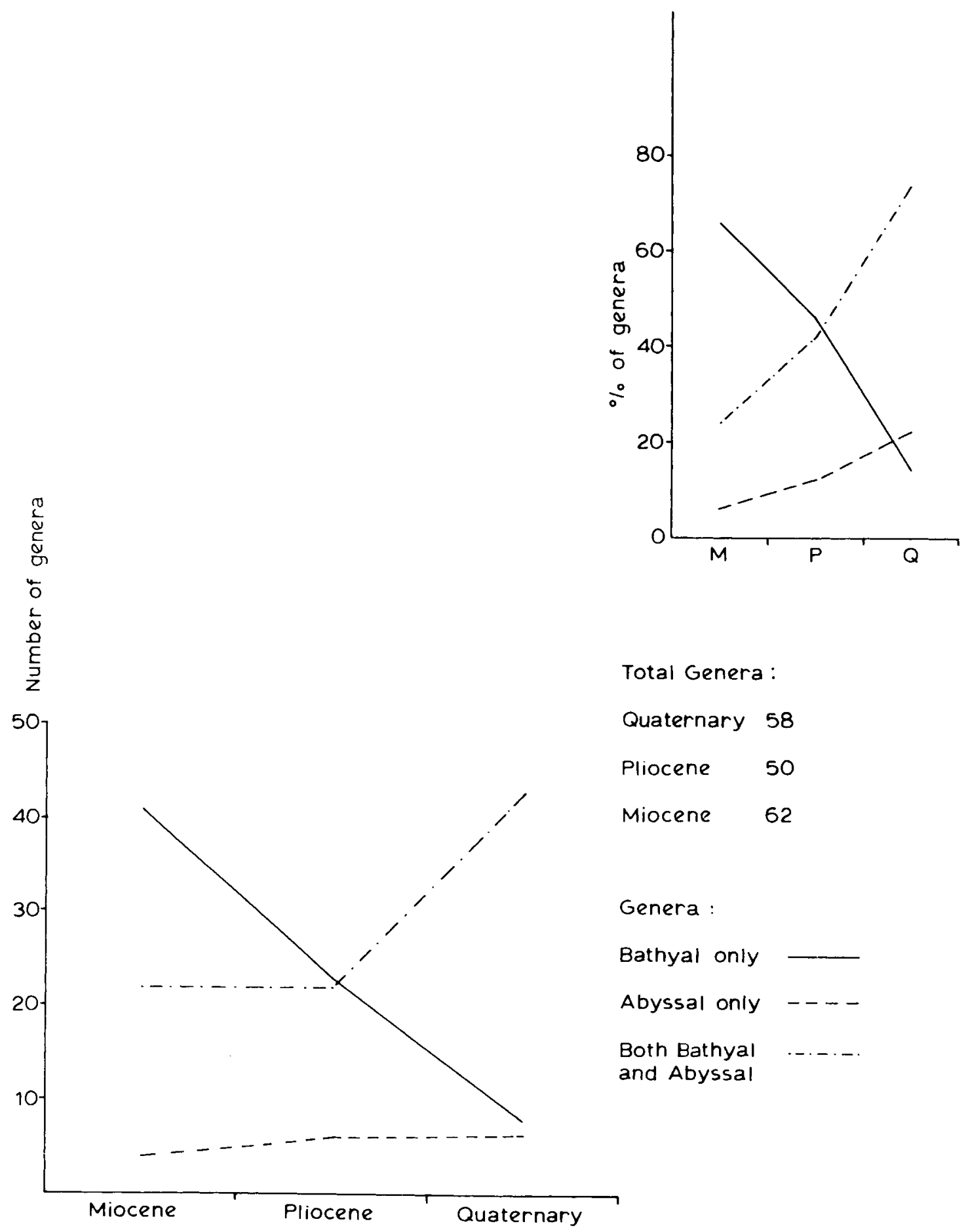


genus is represented by 17 species of which $11(64.7 \%)$ are bathyal only, $5(29.4 \%)$ are abyssal only and just 1 $(5.9 \%)$ occurs in both realms. In the Pliocene there is a decline to 11 species of which $9(81.8 \%)$ are bathyal only, none are abyssal only and $2(18.2 \%)$ occur in both realms. The number of species almost doubles into the Quaternary with 21 of which $9(42.9 \%)$ are bathyal only $7(33.3 \%)$ are abyssal only and $5(23.8 \%)$ occupy both realms.

Argilloecia and the species of the group as a whole clearly show the progressive invasion of the abyss. From Table 2 other genera can be selected, such as Neonesidea, Bairdoppilata, Bythocypris, Zabythocypris, Propontocypris, Australoecia and Paracypris which in varying degrees illustrate the same phenomenon.

In group 2, both Krithe and Parakrithe are thought to have been early invaders of the deep sea and this is largely confirmed by Table 2 and Figs. 6 and 7. It is interesting to note that no pre-Quaternary species of these genera are known to occur in both realms. In the Quaternary, while no Parakrithe species are both bathyal and abyssal, a large number (15) and percentage (28\%) of Krithe species are encountered in both realms for the first time.

Krithe seems better adapted to deep sea environments than any other ostracod genus and the author's experience is that it is similarly highly diverse in all the world's oceans from the late Palaeogene onwards. This high diversity has been masked by the taxonomic "lumping" of species of the genus by previous authors, such as Peypouquet $(1975,1977,1975)$ who regard most Krithe species as being capable of contemporaneously existing as distinct ecomorphotypes at different depths and which exhibit as much as $200 \%$ size (length) difference between them. In a subsequent paper it is intended to present a more realistic taxonomic treatment of the genus.

All species of the Bythocytheridae (group 3) are bathyal only in the Miocene and Pliocene. While the number of such species, after declining in the Pliocene, remains constant overall, the number of abyssal only species in the Quaternary which first appear at that time, exceeds the former. Only one species of this group, in the Quaternary, occurs at both bathyal and abyssal palaeodepths.

Table 2 shows that 5 bythocytherid genera are confined (in this study) to the Miocene; that 3 genera occur for the first time in the Pliocene and a further 4 in the Quaternary. Bythocythere probably illustrates the invasion of the deep sea best; Bythoceratina rather less convincingly. Pseudocythere appears for the first time in deep water in the Quaternary with ${ }^{2 / 3}$ of its species confined to the abyss.

The four genera of group 4 collectively illustrate a small decline in numbers of bathyal only genera (Fig. 6) but a steep decline in their percentage (Fig. 7). The over- all increase in abyssal only species and those occurring in both realms is also well demonstrated in both Figs. 6 and 7 .

Cytheropteron and Aversovalva (Table 2) particularly clearly illustrate the invasion of the abyss. Cytheropteron is represented in the Miocene by 30 species of which 22 $(73.3 \%)$ are bathyal only, $6(20 \%)$ abyssal only and just $2(6.6 \%)$ occur in both realms. In the Pliocene a similar depth distribution obtains with, of the 31 species, 26 (83.9\%) being bathyal only, $(9.7 \%$ abyssal only and again $2(6.4 \%)$ being found in both realms. There are 57 Quaternary species of which $23(40.3 \%)$ are bathyal only and a similar number $22(38.6 \%)$ are abyssal only. Twelve species $(21.1 \%)$ occur at both bathyal and abyssal palaeodepths. Aversovalva follows a very similar trend.

The Trachyleberididae (group 5) exhibit a steep decline in the number of bathyal only species from Miocene to Pliocene with a partial recovery into the Quaternary. This is matched by their percentage. Abyssal only species increase to the Pliocene, then maintain their numbers although their percentage declines. The most notable feature of this group is the regular steep increase, in the Miocene to Quaternary interval of species which are both bathyal and abyssal in their distribution. The progressive invasion of the abyss is best shown in Bradleya and Poseidonamicus (Table 2, Whatley et al., in press a, b, c).

Although a very heterogenous mixture of genera, the species of group 6 also clearly demonstrate the increase in the number and percentage of abyssal only species at the expense of the bathyal only species. Species of this group found in both realms remain low throughout the interval studied.

Fig. 8 largely confirms what earlier figures have demonstrated with respect to the abyssal invasion, in this case by illustrating the percentage of genera which are bathyal only, abyssal only, or which occur in both realms.

While all genera in groups 2 and 4 belong to the latter category, each of the other groups shows a steep overall decline in the percentage of bathyal only genera with a concomittant increase in the percentages of abyssal only genera (groups 3 and 6) and genera with species occurring in both environments (groups $1,3,5,6$ ).

The evidence given above clearly indicates that a distinct ecological shift took place among deep sea Ostracoda in this region from the Miocene to the Quaternary. This resulted in enhanced abyssal specific diversities by the Quaternary, an absolute and proportional decrease in bathyal diversity and a notable increase in those species able to exist in both bathyal and abyssal palaeodepths. This evidence is based on data obtained from all 18 DSDP sites plus the samples from the Loyalty Basin, not all of which have strata of each of the ages concerned, or have been studied for only parts of the stratigraphical solumn. 


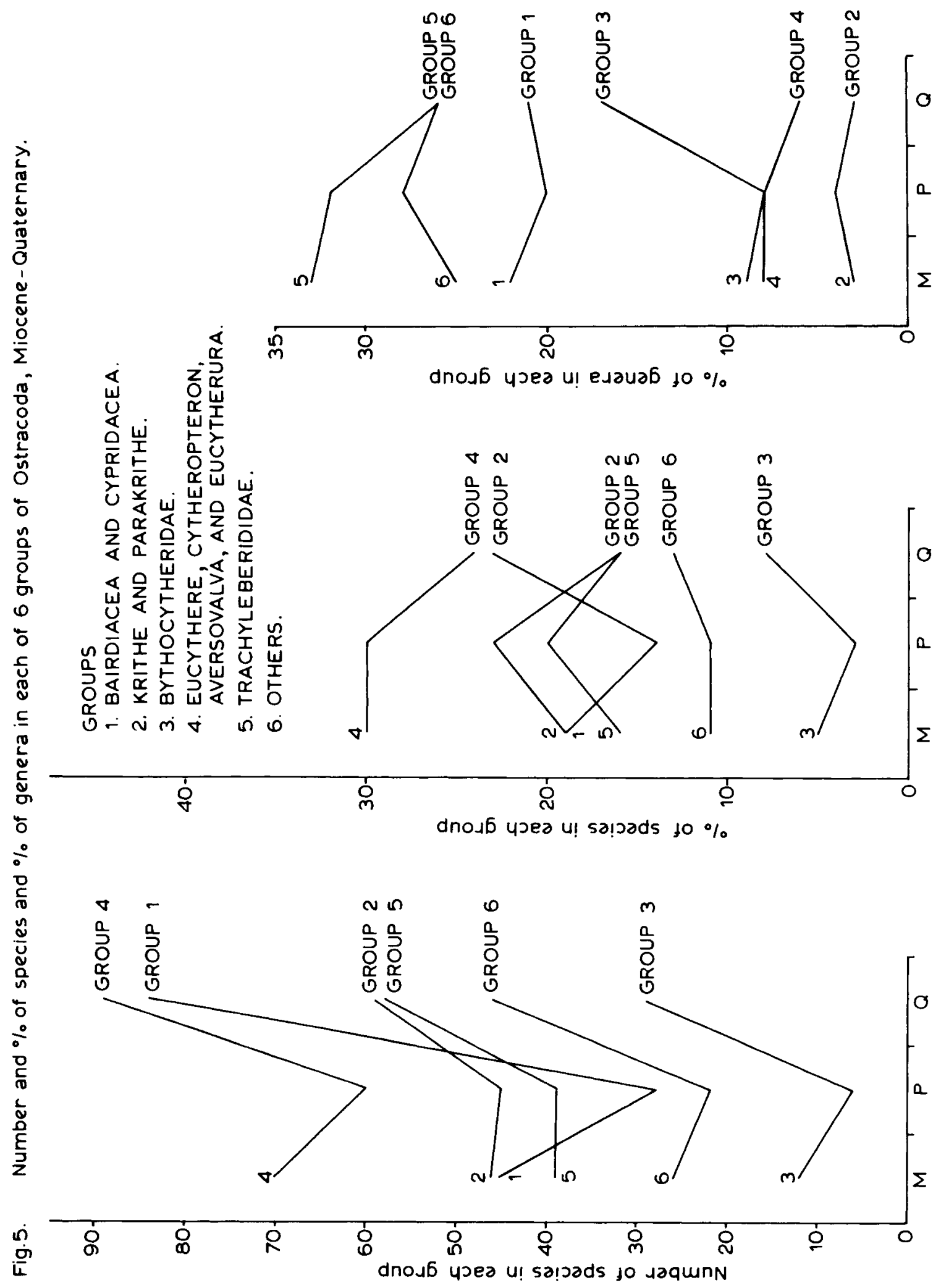


Fig.6. Number of species either bathyal, abyssal or both in each group, Miocene - Quaternary.

Key as in Fig. 4.
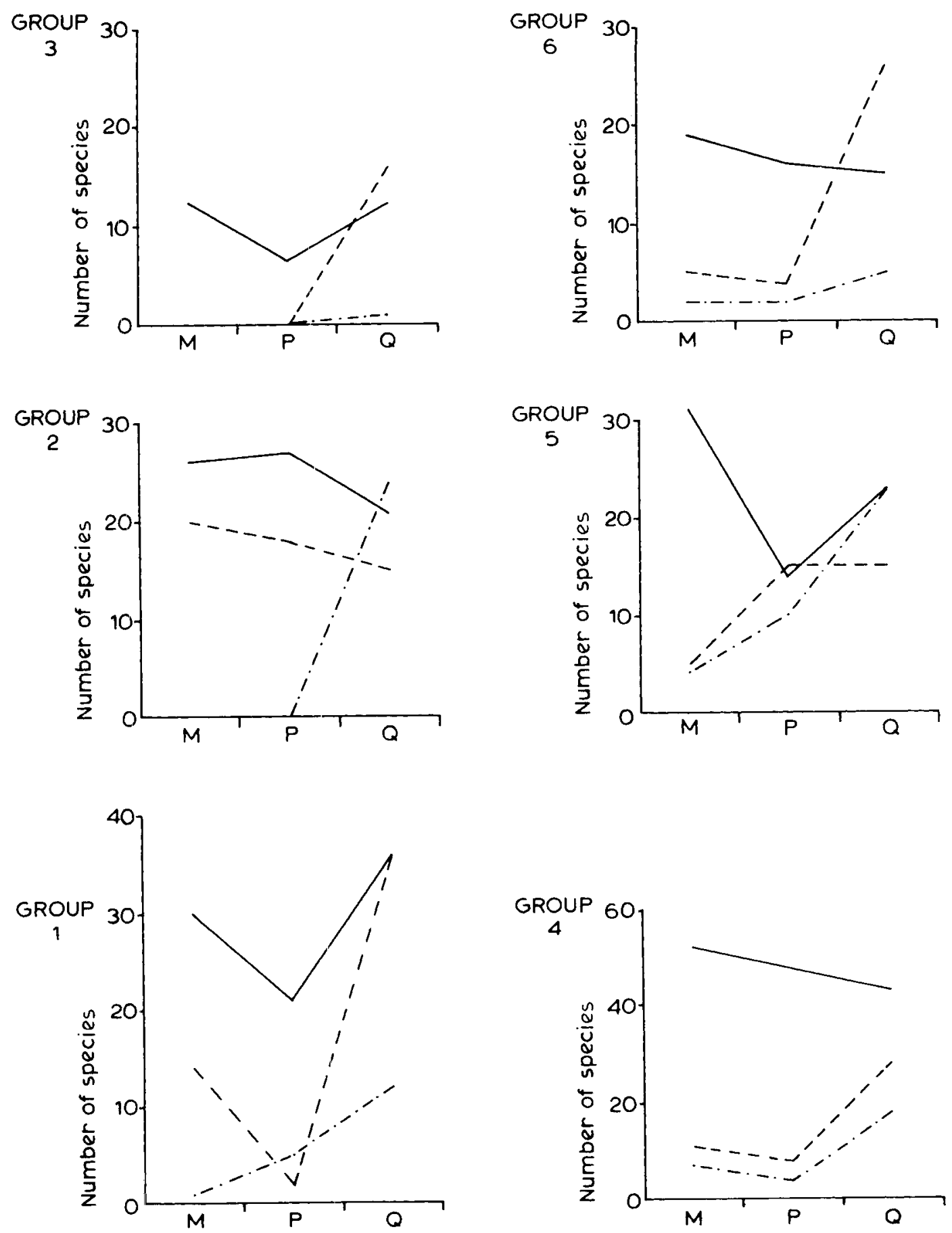
Fig.7. $\%$ of species, either bathyal, abyssal or both in each group.
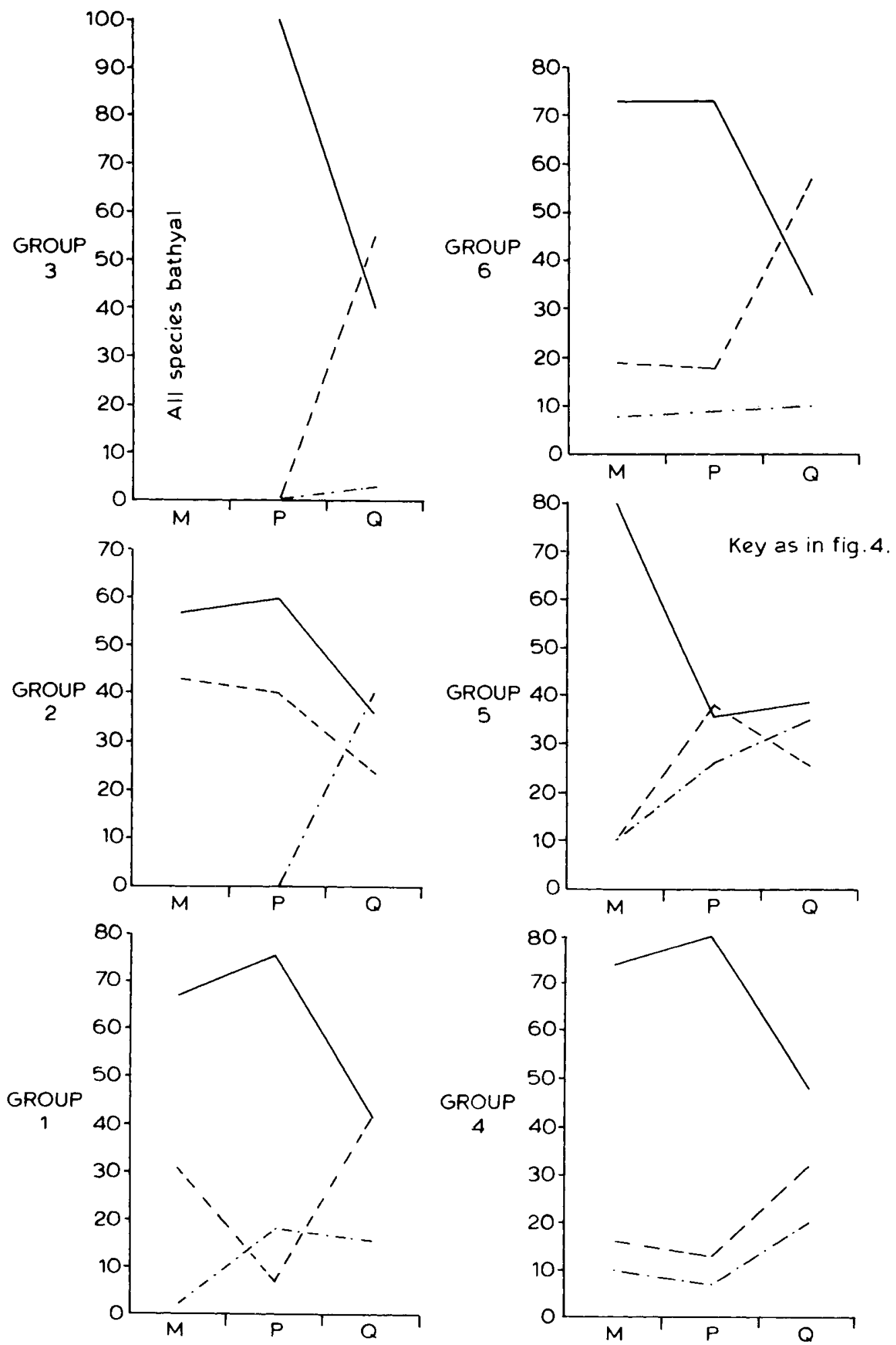
Fig.8. $\%$ of genera either bathyal, abyssal or both in each group, Miocene-Quaternary.

GROUP 4. All genera both Bathyal and Abyssal, Miocene-Quaternary

GROUP 2. All genera both Bathyal and Abyssal, Miocene-Quaternary
Bathyal only

Abyssal only ---

Both Bathyal ....-.. and Abyssa!
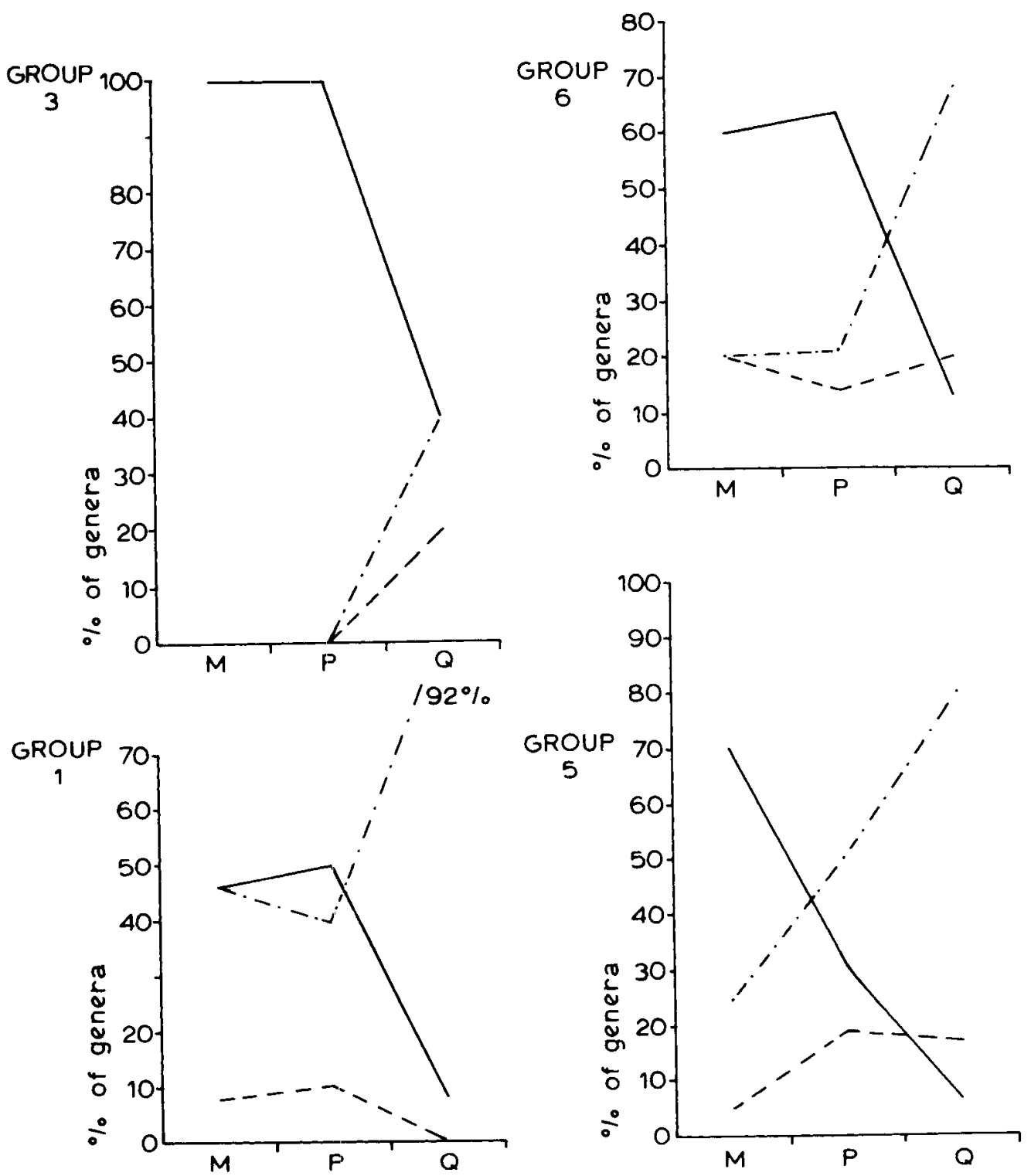


\section{AN ANALYSIS OF THE FAUNAS OF FIVE SITES; MIOCENE TO QUATERNARY}

The faunas of 5 sites have been studied continuously and comprehensively from the Miocene to the Quaternary. These are Site 209, on the outer edge of the Queensland Plateau, Sites 207 and 208 on the Lord Howe Rise (these three sites were all at bathyal palaeodepths during the Neogene and Quaternary, ranging between some $1300 \mathrm{~m}$ and $1500 \mathrm{~m}$ ) and Sites 64 and 289 , which straddle the equator (these were at abyssal palaeodepths during this interval; some $2000 \mathrm{~m}$ to $2200 \mathrm{~m}$ ). Fig. 9 provides numerical data on the species from each of the 5 sites. The total number of species at each site clearly shows that diversity thoughout the Neogene and Quaternary was highest at the bathyal sites. Site 64 shows a steep increase in the number of species at that site and Site 289 also shows an increase, although the highest number occurs in the Pliocene. Fig. 9 also illustrates that the number of species common to more than 2 sites is very much reduced. However, in general, there is an increase in the common species between sites with time. Very important is the histogram illustrating the more than threefold increase in the number of species occurring contemporaneously at both bathyal and abyssal palaeodepths from Miocene to Quaternary.

Figs. 10, 11 and 12 plot the number of species common between the 5 sites for the Miocene, Pliocene and Quaternary respectively. The sites are arranged in a very approximate geographical order. With respect to Fig. 10 it is important to note:

1. The relatively low number of species in the abyss compared to the bathyal.

2. The very few species common between bathyal and abyssal sites.

3. The low number of species common to Sites 64 and 289.

4. The rather low number of species common to Sites 207 and 208 and to Sites 208 and 209.

5. The high number of species common to Sites 207 and 209. Although these two sites, on the southern part of the Lord Howe Rise and Queensland Plateau respectively are today separated by abyssal palaeodepths, this intervening area probably only subsided to these depths in the late Palaeogene or earliest Neogene. The high correlation between these two sites is interpreted as reflecting their common origin on an originally integral area of shelf which subsequently subsided to bathyal depths before being divided into two by the central part subsiding still further to abyssal depths. This suggestion does not however, explain the lower correlation between the other bathyal sites in the Miocene.

Fig. 11 illustrates the following:

1. A small but significant increase in the number of species in the abyss.
2. A significant increase in the number of species common to bathyal and abyssal sites.

3. A $40 \%$ increase in the number of species common to Sites 64 and 289.

4. A major increase in the number of species common to Sites 207 and 208 and a marked increase in the number of species common to Sites 208 and 209.

5. A small but significant decrease in the number of species common to Sites 207 and 209.

Fig. 12 completes this history by demonstrating:

1. The presence of many more species in the abyss.

2. A considerably enhanced number of species common to bathyal and abyssal sites.

3. An increase in the number of species at Site 64 although the number at Site 289 has declined since the Pliocene.

4. A slight decrease in the number of species common to Sites 207 and 208 and to Sites 208 and 209.

5. A sustained decline in the number of species common to Sites 207 and 209 which is interpreted as the increasing effect of abyssal separation of the two sites.

This history of events depicted at these 5 sites in the Miocene to Quaternary interval mirrors those discussed earlier with respect to all the sites and illustrated in Figs, 3-8. It provides further evidence for the progressive invasion of the abyss, for a proportional decline in the importance of bathyal only species and for an increase in the number of species able to live at both bathyal and abyssal palaeodepths.

The breakdown of isolation during the Neogene seems also to have occurred on the only guyot we have studied. Although we have only studied Miocene and Pliocene samples on the Ita Mai Tai guyot (Site 200), Fig. 13 illustrates in the species and genera which occur there, both in terms of total numbers and in terms of those taxa which (in this study) are exclusively found there, a steep decline from the Miocene to the Pliocene.

\section{CONCLUSIONS}

The following conclusions can be drawn from this study:

1. Neogene and Quaternary bathyal and abyssal faunas in the S.W. Pacific exhibit a much higher generic and specific diversity than previous studies would suggest. From my own observations this can certainly be applied to most and probably to all of the world's oceans.

2. In the areas studied, there is a decline in both specific and generic diversity from the Miocene to the Pliocene. followed by an increase, very marked for species, to the Quaternary. While the high diversity of the Quaternary in this area is probably nearly matched in the N. Atlantic (personal observation), not enough evidence exists to substantiate the Pliocene decline elsewhere in the deep sea. Shelf faunas do not reflect this Pliocene decline which may be more apparent 


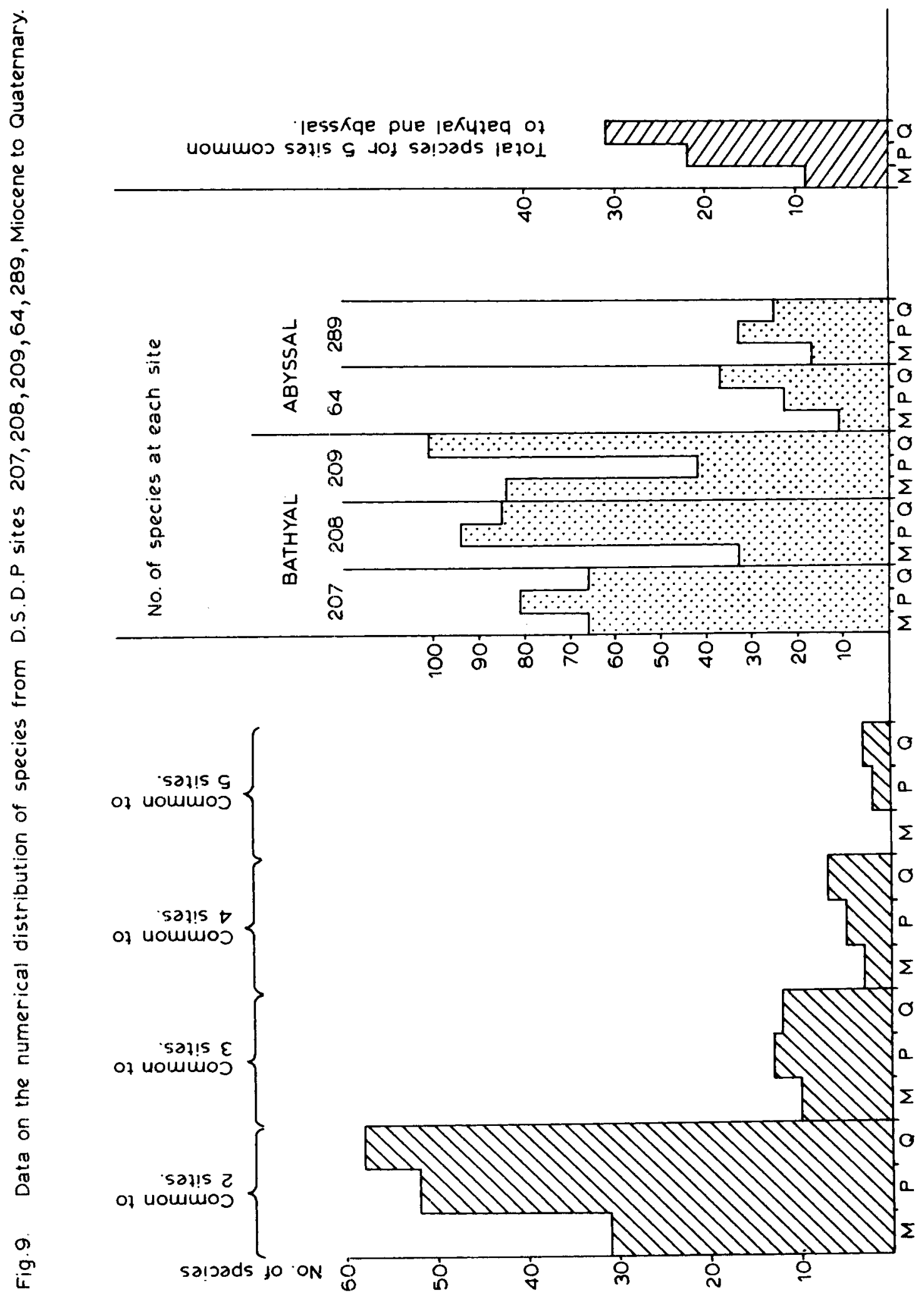




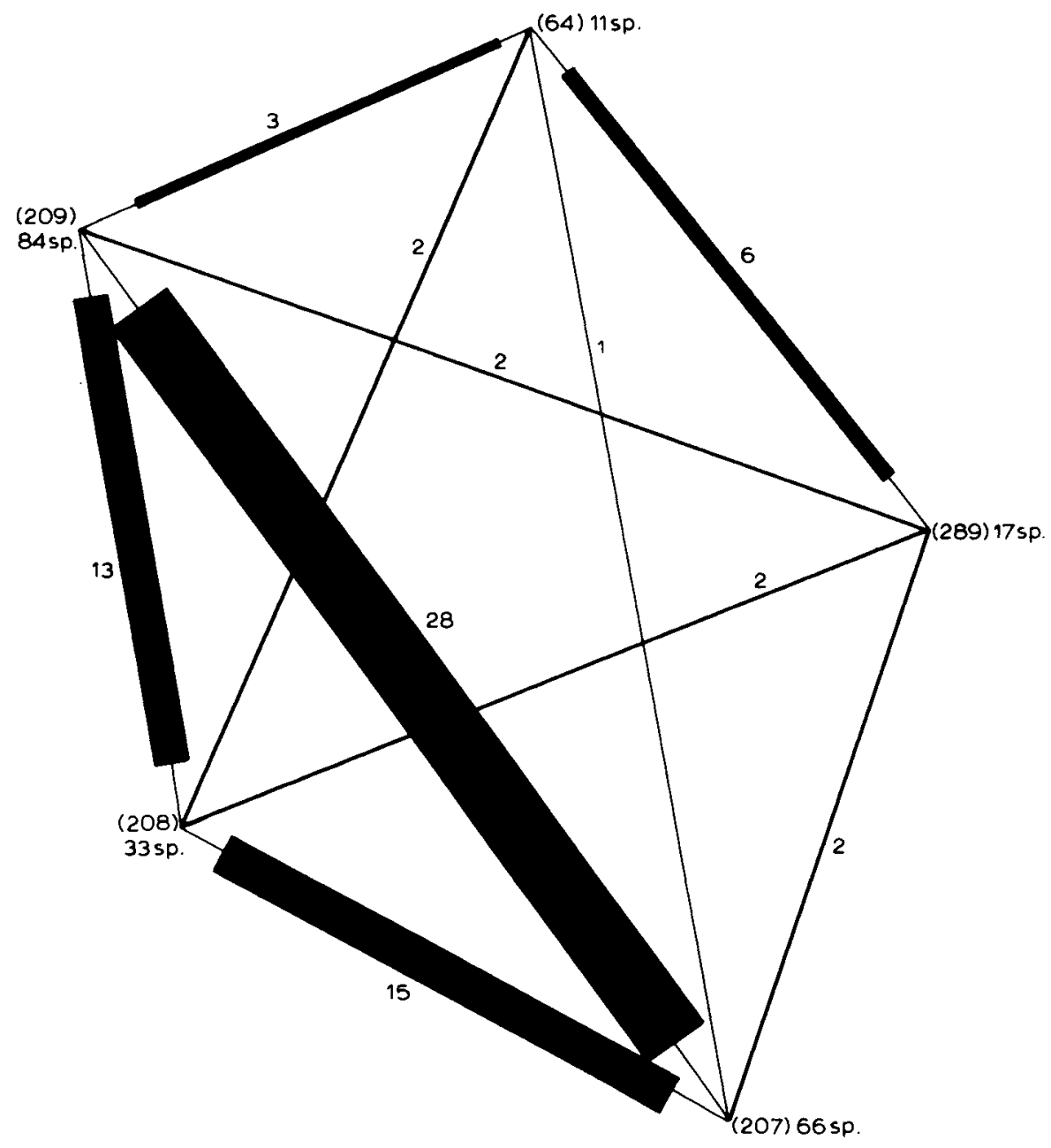

than real. That Miocene diversity is abnormally high is suggested by studies on Bradleya and Poseidonamicus (Whatley et al., in press $\mathrm{a}, \mathrm{b}, \mathrm{c}$ ).

3. A major downslope invasion of the abyss took place between the Miocene and Quaternary in the S.W. Pacific. Species confined to bathyal palaeodepths decline in numbers and percentage and those species confined to abyssal palaeodepths, together with those which occur in both environments, increase substantially. Although insufficient evidence exists to prove that this phenomenon is a universal one, personal knowledge of Indian and Atlantic Neogene and Quaternary faunas suggests that this is possibly so. The causes of this invasion are not certain. It may be associated with major palaeoceanographic or palaeoclimatic events or it may be the culmination of a process long in existence. It is hoped that our studies on the Palaeogene will help to resolve this.

4. In general, each of the 6 groups into which the fauna has been divided, exhibit the phenomena outlined in 1-3 above.

5. A study of 5 sites, continuously studied from the Miocene to the Quaternary, confirms the conclusions drawn in 1-3 above which were made on the basis of a study of all 18 sites.

6. The fauna isolated at bathyal depths on the Ita Mai Tai guyot surrounded by an extensive and very deep abyssal plain, diminished in both numbers and its degree of endemism from the Miocene to the Pliocene. 


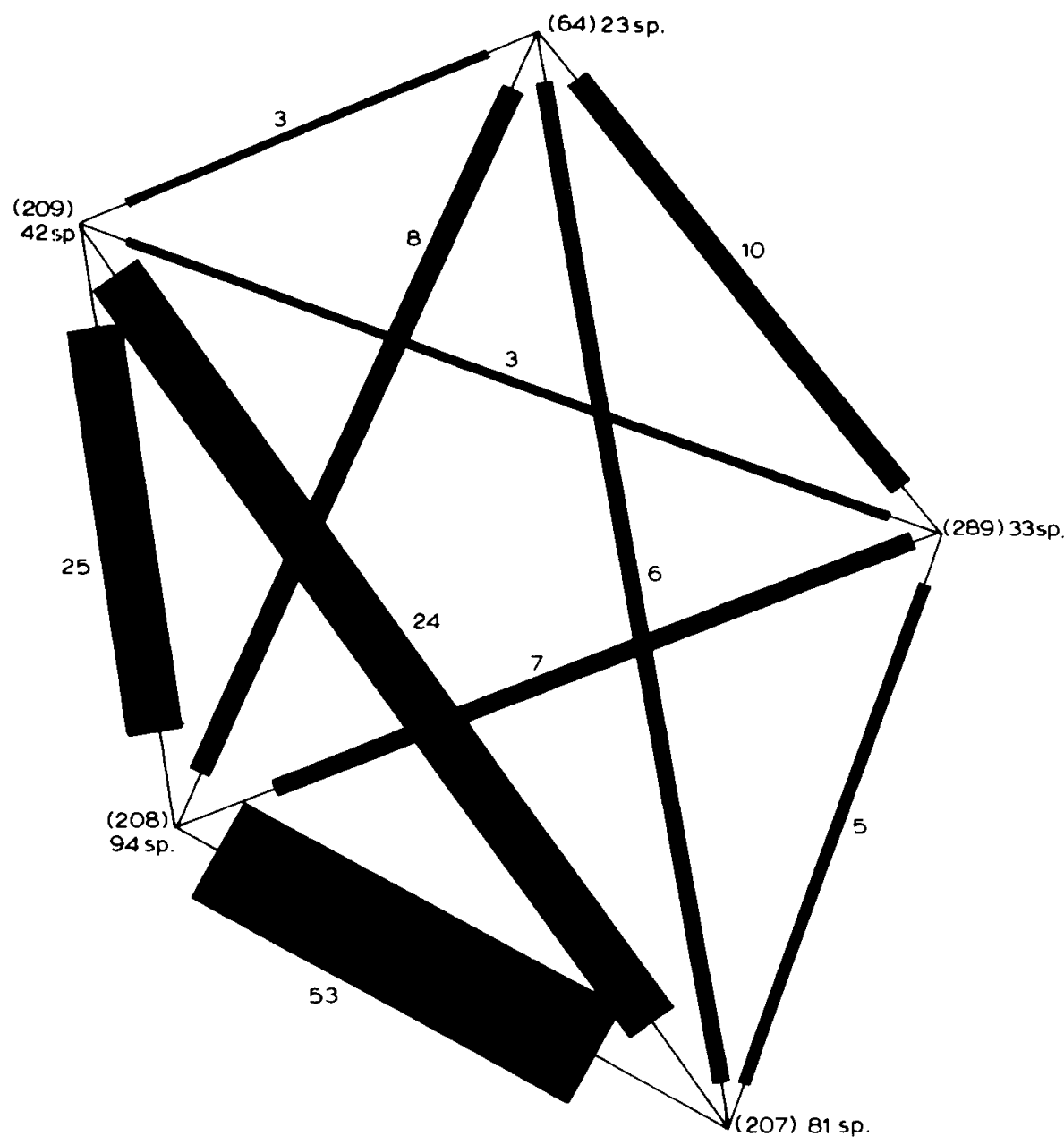

Any conclusions drawn from this study cannot, for the moment, be proved to be applicable to other areas. Also, since it is believed that in this area there exists, between Australia and New Zealand, an important locus of involuntary tectonically controlled induction into the deep sea, it is possible that the results obtained for the S.W. Pacific may be atypical. Notwithstanding these qualifications, however, as yet unpublished and incomplete, studies on the northern Indian Ocean and North Atlantic do suggest that certain aspects of the conclusions which can be drawn from this study of the S.W. Pacific Neogene and Tertiary may be more generally applicable. This seems particularly likely with respect to the largely post-Miocene invasion of the abyss.

Continuing research in the Palaeogene of the S.W. Pacific and in the Neogene and Quaternary of the North Atlantic will, it is hoped, resolve these matters one way or the other in the future and allow consideration of the causes of this migration.

\section{ACKNOWLEDGEMENTS}

This paper could not have been written without the data so generously provided by my three doctoral students, Karin Kesler, Chris Harlow and Sîan Downing who are working on the Palaeogene, Miocene and Pliocene ostracod faunas respectively. Other data was provided by Liz Dainty, Pete Smith and Mike Ayress, Magister students all working on Quaternary faunas. To all six I extend my most sincere gratitude, not merely for the data nor for their excellent level of achievement on their respective projects, but also for much useful and stimulating discussion. I extend the same thanks to various of my colleagues at Aberystwyth.

The clarity of the illustrations is due to Mr. Arnold Thawley and Marian Mayes typed the manuscript. Sian Downing kindly read the manuscript and made many helpful suggestions. 


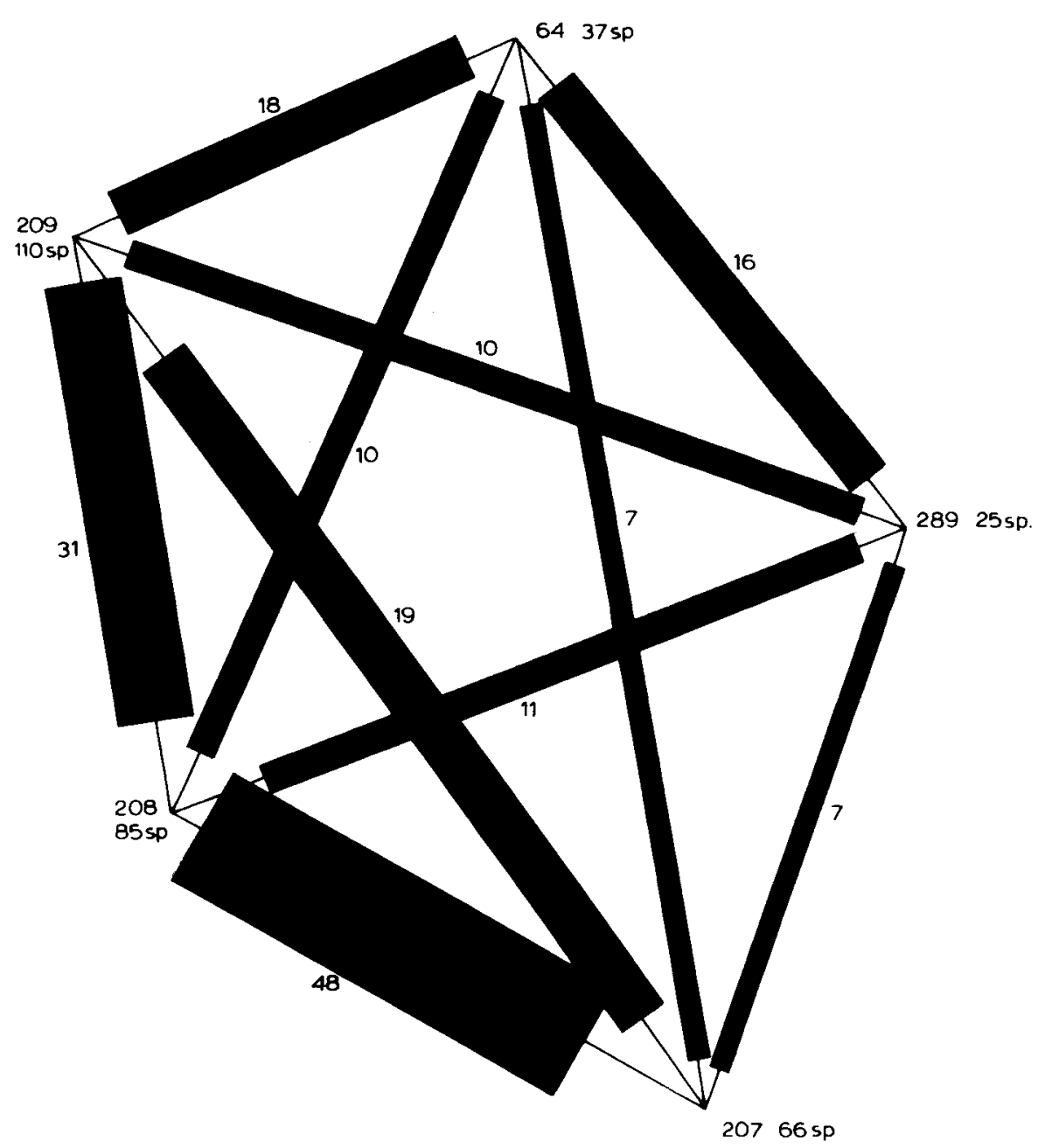

\section{REFERENCES}

Bate, R.H. 1972. Upper Cretaceous Ostracoda from the Carnarvon Basin, Western Australia. Palaeontology Spec. Pap., London, 10, 85 pp., 27 pls.

Benson, R.H. 1969. Preliminary Report on the Study of Abyssal Ostracoda. In Neale, J.W. (Ed.), The Taxonomy Morphology and Ecology of Recent Ostracoda, 475-460. Oliver \& Boyd, Edinburgh.

Benson, R.H. 1971. A New Cenozoic Deep-Sea Genus, Abyssocythere (Crustacea: Ostracoda: Trachyleberididae), with Descriptions of Five New Species. Smithson. Contr. Palaeobiol., Washington, 7, 25 pp.

Benson, R.H. 1972a. The Bradleya Problem with Descriptions of Two New Psychrospheric Ostracode Genera, Agrenocythere and Poseidonamicus (Ostracoda: Crustacea). Smithson Contr. Palaeobiol., Washington, 12, 138 pp.
Benson, R.H. 1972b. Ostracodes as Indicators of Threshold Depth in the Mediterranean during the Pliocene. In Stanley, D.J., (Ed.), The Mediterranean Sea, 63-73. Dowden, Hutchinson \& Ross, Stroudsbury, Pa.

Benson, R.H. 1974. Preliminary Report on the Ostracodes of leg 24. In R. L. Fisher and E. T. Bunce et al. Init. Repts. Deep Sea Drilling Project, 24, 1037-1043.

Benson, R.H. 1975. The origin of the psychrosphere as recorded in changes of deep-sea ostracode assemblages. Lethaia, Oslo, 8, 69-83.

Benson, R.H. 1976. Miocene deep-sea Ostracodes of the Iberian Portal and Baleanic Basin. Marine Micropalaeontology, 1, 249-262. 
Fig.13. Total number and number of species and genera confined to the Ita Mai Tai Guyot, D. S.D.P. 200 (Not sampled in Quaternary)
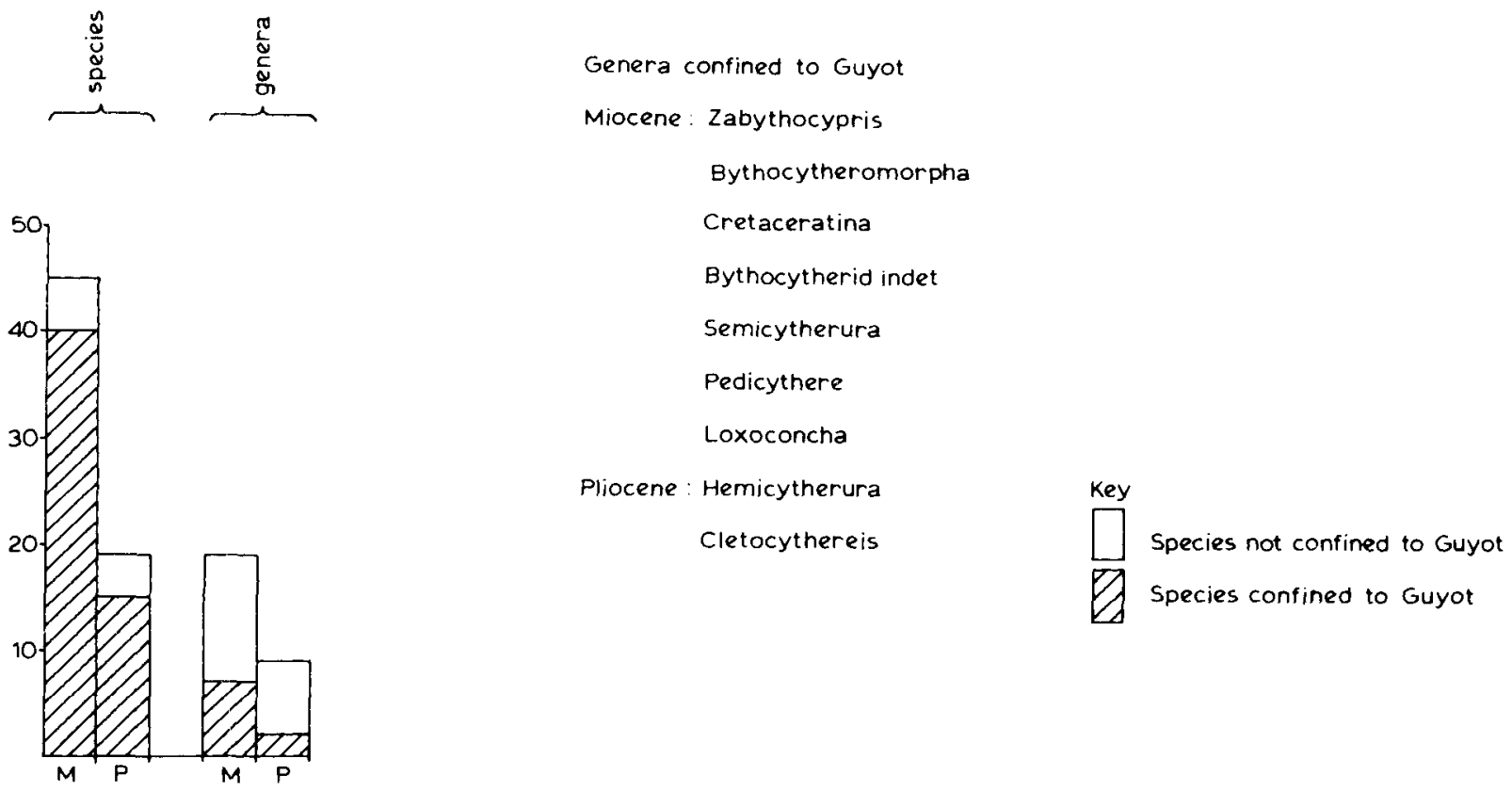

Benson, R.H. 1977. The Cenozoic Ostracode fauna of the Sao Paulo Plateau and the Rio Grande Rise (DSDP Leg 39, Sites 356 and 357). In P. R. Supko and K. Perch-Nielson et al. Init. Repts. Deep Sea Drilling Project, 39, 860--883.

Benson, R.H. 1978. The Palaeoecology of the Ostracodes of DSDP Leg 42A. In K. Hsu and L. Montadert et al. Init. Repts. Deep Sea Drilling Project, 42 (1), 777-787.

Benson, R.H. 1982. Comparative transformation of shape in a rapidly evolving series of structural morphotypes of the ostracod Bradleya. In Bate, R.H., Robinson, E. \& Sheppard, L. M. (Eds.), Fossil and Recent Ostracods, 147-164. Ellis Horwood Ltd., Chichester for the British Micropalaeontological Society.

Benson, R.H. \& Sylvester-Bradley, P. C. 1971. Deep Sea Ostracodes and the transformation of ocean to sea in Tethys. In. Oertli, H.J. (Ed.), Proceedings of the Colloquim on the Palaeoecology of Ostracodes. Rept. S.N.P.A. Pau, 5 suppl., 63-91.

Brady, G.S. 1880. Report on the Ostracoda dredged by the H.M.S. Challenger during the years 1873-1876. Reports on the Voyage of H.M.S. Challenger, Zoology, 1, 1-184.

Burns, E.R. \& J.E. Andrews, 1973. Regional aspects of the Deep Sea Drilling in the southwest Pacific. Init. Repts. Deep Sea Drilling Project., 21, 897-906.

Ducasse, O. \& Peypouquet, J. P. 1979. Cenozoic Ostracodes: Their importance for bathymetry, hydrology and biogeography. Init. Repts. Deep Sea Drilling Project, 48, $343-363$.
Hornibrook, N. de B. 1952. Tertiary and Recent Ostracoda of New Zealand. Palaeontological Bulletin (New Zealand Geological Survey), 18, 1-82.

Joy, J. A. \& Clark, D. L. 1977. The distribution, ecology and systematics of the benthic Ostracoda of the Central Arctic Ocean. Micropaleontology, New York, 23 (2), 129-154.

Keij, A.J. 1979a. Brief review of type species of genera from the Kingma Collection. Proceedings 7 th Int. Symp. on Ostracodes, Beograd, 1979, 59-62.

Keij, A.J. 1979b. Review of the Indo-westpacific Neogene to Holocene ostracode genus Atjehella. Proc. K. ned. Akad. Wet., Ser. B, Amsterdam, 82 (4), 449-464.

Kingma, J. Th. 1948. Contributions to the knowledge of the Young-Cenozoic Ostracods of the Malayan Region, $119 \mathrm{pp}$. Kenin K. Printers, Utrecht.

Malz, H. 1981. Paläoäne Ostracoden von den Emperor Seamounts. N.W.-Pazifik. Zitteliana, 7, 3-29.

McKenzie, K.G. 1974. Cenozoic Ostracoda from Southeastern Australia with the description of Hanaiceratina new genus. Geoscience and Man, Baton Rouge, 6, 153-182.

Moore, T.C., Pisias, N.G. \& Keigwin, L.D. 1981. Ocean basin and depth variability of oxygen isotopes in Cenozoic benthic foraminifera. Marine Micropalaeontology, 6 (5/6), 465-481.

Neale, J,W. 1975. The Ostracod fauna from the Santonian Chalk (Upper Cretaceous) of Gingin, Western Australia. Palaeontology Spec. Pap., London, 16, 1-81. 
Packham, G.H.\& Andrews, J.E. 1975. Results of Leg 30 and the Geologic History of the South-West Pacific Arc and Marginal Sea Complex. Init. Repts. Deep Sea Drilling Project, 30, 691-705.

Peypouquet, J-P. 1975. Les variations des caractères morphologiques internes chez les Ostracodes des genres Krithe et Parakrithe: relation possible avec le teneur en $\mathrm{O}_{2}$ dissou dans l’eau. Bull. Inst. Géol. Bassin Aquitaine, 17, 81-88.

Peypouquet, J-P. 1977. Les Ostracodes et la connaisance des paleomilieux profonde. Appliation au Cenozoique de l'Atlantique Nord-Oriental. Thèse Doct. Etat, Université de Bordeaux J. No. 552, 443 pp.

Peypouquet, J-P. 1979. Comment at purquoi l'environment épibathyal du debut du Neogene est-il different de celui de la fin du Quaternaire dans le Golfe de Gascogne? Bull. Soc. géol. Fr., Paris, 7, 21 (5), 569-574.

Puri, H.S. \& Hulings, N.C. 1976. Designation of Lectotypes of Some Ostracods from the Challenger Expedition. Bull. Br. Mus. nat. Hist. London, (Zool.), 29 (5), 254-314.

Savin, S.M., Douglas, R.G.\& Stehli, F.G. 1975. Tertiary marine palacotemperatures. Bull. geol. Soc. Am., New York, 86 (11), 1499-1510.

Shakleton, N.J. \& Kennett, J.P. 1975a. Palacotemperature history of the Cenozoic and the Initiation of Antarctic Glaciation: Oxygen and Carbon isotope analysis in D.S. D.P. Sites 277, 279 and 281. Init. Repts. Deep sea Drilling Project, 29, $743-7.54$.

Shakleton, N.J.\& Kennett, J. P. 1975b. Late Cenozoic Oxygen and Carbon Isotopic changes at D.S.D.P. Site 284; Implications for glacial history of the Northern Hemisphere and Antarctic. Ihid., 801-807.

Steineck, P.L. 1981. Upper Eocene to middle Miocene ostracode faunas and palaeo-oceanography of the North Coastal Belt, Jamaica, West Indies. Marine Micropalaeontology, 6 , $339-366$.
Swain, F. M. 1970a. Pliocene Ostracodes from Deep-Sea Sediments in the Southwest Pacific and Indian Ocean. In Funnel, B.M. \& Riedel, W.R. (Eds.), The Micropaleontology of Oceans, 597-599.

Swain, F. M. 1970b. Pleistocene Ostracoda from Deep-Sea Sediments in the Southeastern Pacific Ocean. Ibid., $487-$ 488.

Swanson, K. M. 1969. Some Lower Miocene Ostracoda from the Middle Waipara District, New Zealand. Trans. Roy. Soc. N.Z. Earth Sci., 7 (3), 33-48.

Whatley, R.C. \& Downing, S.E. In Press. Middle Miocene Ostracoda from Victoria, Australia. Rev. Esp. de Micropal.

Whatley, R.C., Harlow, C.J., Downing, S.E. \& Kesler, K. J. In Press a. Some observations on the origin, evolution, dispersion and ecology of the genera Poseidonamicus Benson and Bradleya Hornibrook. Proceedings 8 th Int. Symp. on Ostracoda, Houston, 1982.

Whatley, R.C., Harlow, C.J., Downing, S.E. \& Kesler, K.J. In Press $b$. The origin and evolution of the ostracod genus Poseidonamicus Benson with the description of new species from the Tertiary of D.S.D.P. Sites in the S.W. Pacific. Marine Micropalaeontology

Whatley, R.C., Harlow, C.J., Downing, S.E. \& Kesler, K.J. In Press c. Some further observations on the Bradleya Problem (Crustacea, Ostracoda) with the description of new Tertiary species from D.S.D.P. sites in the S.W. Pacific. Palaeontology, London.

Whatley, R. C., Uffenorde, H., Harlow, C. J., Downing, S.E.\& Kester, K.J. 1982. The Rockalliidae, a new family of Cainozoic Ostracoda. I. micropalaeontol., London, 1, 1-19. 